\title{
Poland on the Route of the Chinese Silk Road: A Chance for Development or Just a Challenge?
}

The two Chinese Silk Roads going to Europe, announced in autumn 2013, surprised not only European and global political elites, but academic circles as well. This unprecedented project or vision of Chinese President Xi Jinping draws attention with its spectacular scale and range. It is the proof of China's rebirth as a power and of its global ambitions. The aim of this study is to show how the project is referred to by the elite of the European Union countries, the region of Central and Eastern Europe, involved in the other Chinese strategy, 16+1, and by Poland, which found itself directly on the land route. What did Poland do with this opportunity? The analysis shows that relatively little - despite the noticeable Chinese presence and interests located here. Therefore, the Silk Roads remain a rather untapped potential opportunity for Warsaw than a real new development opportunity. To change this, a political will is required which seems to be lacking on the Polish side.

Keywords: Belt and Road Initiative - BRI; Strategy 16+1; China; Europe; Geopolitics; Development Strategies; New Economic Order

\section{Introduction}

Announced in autumn 2013 in two rounds by President Xi Jinping, the project, or rather a geostrategic vision, in the original called Yidai, yilu, first introduced to the international audience as One Belt, One Road (OBOR), and then BRI (Belt and Road Initiative), at the time of its appearance aroused consternation even in China itself, not to mention the outside world. It was announced by the country that so far has been keeping in line with taoguang, yanghui formula dictated by the visionary reformer Deng Xiaoping in the early 90 s of the last century, that is building the power quietly, without attracting anyone's attention, trying "to conceal its capabilities and avoid the limelight'. Afterwards it came up with an unprecedented project, the implementation of which can bring about a significant change of the balance of power in the world. 
In China, this idea was quickly translated into concrete actions: in all the major academic centers of the country special teams, faculties, and even research institutes were established to constitute the scientific background of the BRI, with the basic task to fill this concept with substantive content. As initially, at the very beginning of that road, there were only five proposals of the President of China for countries that would like to join the project: policy coordination, better communication (road and rail), open trade, financial exchange, and closer cooperation between the citizens. ${ }^{1}$

Very soon, the Chinese scientific community and experts revealed that this is about something more - in essence, about showing China as a new geostrategic player, benefiting from its rapidly growing economic and financial potential, returning to the status of a superpower and a great center of strength and ideas that China has held for centuries before (Maddison, 2007). And some have even admitted that when creating this concept, China reached out to the ideas of "geostrategic fathers", that is Halford John Mackinder and Nicholas Spykman, talking about the Heartland connecting Europe and Asia and the surrounding chain of the seas and oceans, i.e. Rimland (Zhang, 2016, p. 28; Bartosiak, 2016, p. 70, 71). The distinctive feature of this concept is that those Silk Roads, both land and maritime, are heading towards the West, first of all to Europe (though with branches to the Middle East and even to Africa, and with time it turned out that some of the projects within them were initiated even in Thailand or Indonesia).

The concept of OBOR, and later BRI (the Chinese name remained the same) in the outside world, and above all in the broadly understood West, was met not only with surprise, but also with mixed feelings. Yes, there have been opinions that the BRI is "the most significant and far-reaching initiative that China has ever presented" (Winter, 2016). However, much more often the thesis was made saying that a new heaviest weight player entered the world stage, which naturally aroused the greatest consternation in the USA, the current hegemonic power on the world stage.

A bulky proof of this thesis is the book of Michael Pillsbury who spent his whole life in the American intelligence-analytical community dealing with China. After the publication of the OBOR concept, he published a volume with the significant title of "The Hundred-Year Marathon", in which he referred to yet another strategic concept of Xi Jinping, concerning "the two centennial goals". The first goal, for the centenary of the ruling Communist Party of China (CPC), to be implemented in mid-2021, is the change of the local economic model and basing it not on exports, as it used to be, but on a strong and thriving

1 Land Silk Road announced on September 7, 2013 in Astana and the maritime Silk Road announced on October 3, 2013 in Bali, Indonesia (see Xi, 2014, p. 315, 320). 
middle class and dynamic domestic market. The second "centennial goal", for a round hundredth anniversary of the proclamation of the People's Republic of China (PRC), and thus to be completed on October 1, 2049, is nothing else, then the "great renaissance of the Chinese nation", which requires meeting a number of serious requirements, including the most crucial one - a peaceful unification with Taiwan, because until now we are, after all, dealing with two organisms with China in the name (On the new development model: Góralczyk, 2017b, p. 41-55.On the new geopolitical strategy: Góralczyk, 2018).

According to Pillsbury and many other experts, these "two centennial goals", combined with the BRI, just confirm the emergence of a new geostrategic player, and also the most powerful US rival to the leading role on the globe, to what the United States have contributed for decades, from Henry Kissinger's and President Richard Nixon's visits to the PRC in the early 1970s. According to Pillsbury, that American attitude has appeared to be "perhaps the most systematic, significant and dangerous failure of intelligence in American history" (Pillsbury, 2016, p. 16).

\section{Perception of the BRI}

\subsection{In the European Union (UE)}

The problem is that the Chinese Silk Roads quite unequivocally show a new pretender to hegemony on the world stage, which must raise the understandable consternation of the current hegemon, the USA. Thus, the situation was called by the experts of Harvard University "the Thucydides Trap", when the interests of the current leading power collide with the interests of the pretender, which usually leads to a war, and frequently not only a commercial one. That is what we are observing already now, especially in the South China Sea, controlled so far by the American fleet, but on the shores of which, in the port of Xiamen and a few other places, the Maritime Silk Road has its beginning, which forces the Chinese to increase their presence, also military, in this reservoir. This is an area where the "Thucydides's Trap" is openly set, and the territory of direct clash of influence and interests of the US and the PRC. Thus, both here and across the international arena a confrontation of the two giants seems to be inevitable. ${ }^{2}$

2 The idea comes from a retired and experienced researcher and administrator from Harvard, Graham Allison, who - together with his team - has examined the period from 1500 to the present in this category. It turned out that there were 16 'traps' in that time, 12 of which ended in war. Cf. (See Allison, 2017; or Bartosiak, 2016, p. 554-663). 
The beginning of a real commercial war, initiated in the spring of 2018 by the administration of President Donald Trump, who promotes the slogan America First and in fact isolationism in trade ${ }^{3}$, widespread to a larger extent in September, encounters Chinese retaliation and collides with the free trade policy promoted by the Chinese authorities, without obstacles and inhibitions ${ }^{4}$. Simultaneously we have a paradox situation: while the US is voting for narrow national interests, China is still strongly supporting globalization and open markets, as Xi Jinping so strongly emphasized in his two high-profile speeches at the Davos Economic Forum in January 2017 and at a similar Forum in Boao in April 2018 (Xinhua, 2017; Xi, 2018).

OBOR, and then BRI, were met with mixed feelings also in the EU and its institutions. The approach towards the BRI of the Member States in the EU was also highly diversified. In the analyzes available today (two best and most inquisitive are: Godemont and Vasselier, 2017; MERICS and Rhodium Group, 2017), there are indeed indications of new opportunities and possibilities, following the Chinese concepts and their new presence in Europe. However, so far they are rather unknown, neither as to scale, nor - capital and investment - commitment. Even more often, the other arguments are emphasized, and over time growing and gaining more power. According to them: the Chinese vision has serious shortcomings and faults, such as lack of precision in rearranged maps and BRI routes, forcing the interests of its own companies, is lacking of transparency of proposed contracts, is incompatible with the proposed agreements with EU standards and norms, has many ambiguities regarding financing and public tenders for individual projects, and issues of respecting property rights, as well as paying too much emphasis on bilateral agreements with individual EU Member States that almost without exception suffer from a chronic trade deficit from the PRC, sometimes exceptionally high, which leads, on the one hand, to the "asymmetry of impact and influence", while the other threatens to implement China's "divide and rule" strategies among member states. These opinions and allegations even found a diplomatic reflection when, in April 2018, EU ambassadors in Beijing, with the exception of a Hungarian representative, formulated these claims in writing, starting with the most serious charge - that the implementation of the BRI threatens the breakdown of the EU.5

3 Initial analyses: https://www.project-syndicate.org/bigpicture/trump-s-trade-war-expands (16.07. 2018).

4 https://info.expeditors.com/newsflash/president-trump-announces-200-billion-in-section-301tariffs-on-china My comment: https://www.obserwatorfinansowy.pl/forma/rotator/chiny-usawojna-handlowa-czy-zimna/

5 https://global.handelsblatt.com/politics/eu-ambassadors-beijing-china-silk-road-912258 (access: 20.07.2018). 
The basic shortcoming of the EU in its relations with China - and in general with 'emerging markets' - is the lack of a coherent and uniform strategy towards them, what all the more leads to asymmetry in the light of bold visions within the BRI. Unfortunately, that kind of conclusion comes to our minds, even despite the adoption by the European Commission in November 2013 of the strategic agenda for cooperation in bilateral relations with China for the period up to 2020 and placing there as many as 94 "key initiatives" (EEAS, 2016) regarding this cooperation in not only the economic or trade sphere, but also for example in the field of security and peace, in the field of sustainable development, scientific and scientific cooperation, tourism and personal exchanges.

The second factor, which emerged very soon after the announcement of the Chinese Initiative, is the rapidly growing Chinese investment presence in the EU, which in 2016 reached EUR 35 billion (increase by as much as 77 percent in relation to the previous year), while the EU's presence in the PRC territory reached only EUR 7.6 billion. ${ }^{6}$ For - what should be stressed and emphasized - just one year after the announcement of OBOR's vision, Chinese investments abroad exceeded those coming to China, which have always been high since at least 1992, that is the year of the opening of China to globalization immediately after the collapse of the USSR. This change must be regarded as a Copernican turn in the Chinese development strategy, and stand, to a large extent, behind President's Xi Jinping vision of the BRI. After two decades of global opening China has started to have capital surpluses and investment powers which are and will be properly used not only at home but also on foreign markets.

And finally, the third, crucial element: as it soon turned out, the Chinese side comes to Europe and the EU with new investments, but not in a greenefield form, that is the ideas of building new objects from the foundations, but rather it is interested in merger and acquisition operations, especially acquisitions of companies or brands specializing in modern and newest technologies. It was the acquisition of the Swiss chemical company Syngenta for an estimated sum of 65 billion dollars, and then a German company Kuka, specializing in the production of industrial robots (for an estimated amount of 5.5 billion) that made all European countries, including Germany, the most involved in cooperation with China, to finally realize that they were dealing with a completely new Chinese presence on domestic markets, where the 'crown jewels' are taken over, as it was perceived in media. As a result, even the then foreign minister of Germany, Sigmar Gabriel, began to encourage close cooperation between EU member states and the development of a common strategy for dealing with

6 And all this with a negative trade balance of the EU in the same year of 174 billion euros (see Godemont andVasselier, 2017, p. 37). 
China, because - as he said - "if we fail to work out a common strategy towards China, then China will succeed in dividing Europe" (Godemont and Vasselier, 2017, p. 17).

It was only the takeovers of modern companies and the high investment presence of China on the European continent that, to some extent, "woke up" the EU institutions and the authorities of individual Member States. Finally, they realized that the idea of the BRI is actually being implemented and cannot be in any way ignored, as it was at the very beginning just after its announcement. Its implementation creates a completely new quality in the EU's mutual relations with the PRC, requiring from the EU countries a new consideration, reflection and a real strategy in these completely new circumstances.

At the same time, however, quite understandably, the EU authorities are cautious in accepting Chinese suggestions to "join forces" in a win-win strategy, proposed by Beijing, in order to counter US Donald Trump's initiatives to limit trade and isolate its market. The EU also loses on these American ideas, but quite clearly underlines that the US remains its key strategic partner. In other words, even the threat of a trade war does not mean a change in alliances or a new configuration on the global scene. ${ }^{7}$ In other words, the EU does not bet on China. And what about the CEE region countries?

\subsection{In the Region of Central and Eastern Europe (CEE)}

The specificity of the relations of the CEE region with China is that these countries have also started, on China's initiative, enhanced cooperation with the PRC even before the announcement of the BRI. The previous Prime Minister Wen Jiabao announced in Warsaw in April 2012 the concept of cooperation within the $16+1$ formula invented in Beijing, that is China with 16 countries of the region (four from the Visegrad Group, three Baltic States and the Balkan states, with Romania, Bulgaria and Albania as well as post-Yugoslavian states, without Kosovo). Such and no other composition of the 16 proves that China does not pay too much attention to the EU borders ( 11 members, 5 candidates), and - even more so - the euro area. More convincing was for them the geographical proximity of these countries in the previously poorly recognized and less important region at the gates of a strong Western Europe. A region somewhat diverse but seen mainly from one vantage point: it formerly shared experience of "real socialism" or planned economy.

7 "We don't agree with Trump, but that doesn't mean we want to gang up on America with China, says EU adviser ahead of summit"; seehttps://www.project-syndicate.org/bigpicture/ trump-s-trade-war-expands (16.07.2018). 
Originally, the Chinese side, in the framework of this cooperation, proposed a vision of " 12 projects" or steps and allocated for these purposes a sum of 10 billion dollars. Few of these plans were successfully implemented, and the symbolic "flagship" of this cooperation, that is, a fast Chinese railway connecting Budapest with Belgrade (ultimately it would be about connecting the port of Piraeus, in the hands of the Chinese company Cosco and being an end, thus far, of the Maritime Silk Road, with Łódź, which is an important center in the Chinese transport plans on the route of the land Silk Road). This idea is still not being implemented today, because of resistance - and accusations - of the European Commission due to a "lack of transparency" (more: Góralczyk, 2017, p. 153-162).

Recognizing the problems within this cooperation, as well as the reluctance towards it expressed openly in the EU institutions and major capitals of EU Member States, starting with Berlin, the Chinese side at the $16+1$ summit in November 2016 in Riga, through the head of its delegation, Prime Minister Li Keqiang, came out with another, five-point cooperation proposal. It assumed stimulation of trade, acceleration of construction of transport connections (both infrastructure and logistics), construction of Chinese industrial and technological parks in 16 countries (one of them was already established outside it, in Minsk, Belarus), revival of financial cooperation (the Hungarian National Bank is involved in research projects on the internationalization of the yuan) and increasing the tourism and personal exchange (Oehler-Sincai, 2018, p. 8).

This partial change in priorities has changed little so far, China is apparently still not satisfied with this cooperation. Although the initial assumptions were different and focused on the economy and trade, the level of political cooperation still precedes the level of economic exchange. The only measurable achievement so far in the framework of the $16+1$ initiative is the establishment of its Secretariat based in Beijing ${ }^{8}$ and annual summits, the last of which took place in Sofia in July 2018. ${ }^{9}$ The Chinese side, however, seems to be increasingly moving towards the concept presented by President Xi Jinping to the participants of the Suzhou Summit (November 2015) to "fully integrate" the 16+1 concept with the BRI (Joić, 2017, p. 2). There are also ideas that the $16+1$ summits

8 A separate Secretariat, coordinated by Poland, was also established to coordinate logistic cooperation.

9 They are supplemented by a whole network of other meetings and conventions: four times a year meetings of 16 ambassadors in Beijing, organized once every six months (once in Beijing, once in the state organizing the annual summit) meetings of the National Project Coordinators, complemented by meetings of think tanks and experts. 
should not be - like thus far - annual, but once every two years, which for many observers is a proof that the project, however, did not gain much support.

Nonetheless, before the last summit in Bulgaria, there has been much publicity about an invite for Germany as well. This idea has been pushed for a while by Chinese specialists dealing with Germany, who explicitly treat the entire CEE region as a German sphere of influence in the political and economic dimension. Therefore, as they suggest, the inclusion of Germany in the 16+1 framework would be the best way to remove their expressive suspicions about China's real motives for involvement in this area (Zou, 2018, p. 8, 9).

There is another important element proving the new dynamics of events around this idea, a new geostrategic factor that is the unconventional behavior of the administration and President Donald Trump himself, in relations with China and the Asia-Pacific region as well as transatlantic within NATO and bilateral relations between the USA and the EU. In this context, the Chinese side is looking for new solutions, as evidenced by the visit of the head of the Chinese delegation, Prime Minister Li Keqiang, immediately after the Sofia Summit went to Berlin, where an unprecedented decision was made for the German conglomerate BASF to build its own investment worth 10 billion dollars in the south of China, without the participation of Chinese capital, which is a completely new solution and not used thus far in the PRC. 10

Another valuable achievement of cooperation within the framework of $16+1$ is the establishment in April 2017 in Budapest of the China - CEE Institute by the Chinese Academy of Social Science (CASS) in Beijing, the most serious Chinese think tank working for the authorities, the first of its kind research institute outside China. It was headed by the heads of the CASS European Institute, who had already demonstrated the largest range of research on $16+1$ and BRI (along with a valuable publishing series) ${ }^{11}$ and they are the most valuable research facility in this respect alongside the special China Silk Road Institute instituted in Beijing before the first BRI summit (henceforth to be organized every two years). The Institute in Budapest has already published two valuable series of working papers on cooperation in the framework of $16+1$ and BRI initiatives. Further events and publications are planned, including books. ${ }^{12}$

10 https://cen.acs.org/business/petrochemicals/BASF-considering-10-billion-investment/96/ web/2018/07 (16.07.2018). See also: https://thediplomat.com/2018/07/whats-next-for-the-chinacee-161-platform/

11 Three most valuable works thus far are: Zuokui, 2017; Ping and Zuokui, 2017; Xin, 2017.

12 In the first tranche, published in November 2017, it was more than a dozen studies, in the second, published in June 2018, more than twenty. They are available at www.china-cee.eu and are an important material also used in this study. 
The state of research available so far shows that:

- The countries of the CEE region, like the countries of the whole EU, are quite divided in relation to Chinese initiatives. The most positive are Hungary, the Czech Republic and Romania, and - most recently - the area of the Western Balkans, i.e. the post-Yugoslavian countries, with the leading role in this respect of Serbia. On the other hand, Poland, the Baltic States, Albania and Slovakia are more restrained.

- The investment cooperation in the center in Chinese proposals and interests does not bring the expected results so far, and Chinese investments aimed at Europe are placed primarily in Germany, Great Britain, France, and Italy. Recently, from 2017, there is also a new dynamic in this regard in the Western Balkans (Smederevo metallurgical plants, Kostolac hotspots and the country's first wind farm in Serbia, Rimac electric car factory and renovation of the Krapinske Toplice spa and a bridge on the Pelješac peninsula in Croatia, the "five ports" initiative covering the Italian ports of Trieste, Venice, Ravenna, Slovenian Koper and Croatian Rijeka). At the same time, all research and data show that Serbia is the first partner of China in the Western Balkans, the second country in the framework of the 16, alongside Hungary, with a clear political will to develop this cooperation, which is even more visible in contrast with the region's, including Poland, perceptible disappointment with the state of existing cooperation.

- However, as far as the Chinese investments in the CEE region are concerned, the V4 countries still play a leading role, including the Czech Republic (34\% of the total 16, where Chinese companies have taken over the local airlines, the Sparta Praha sports club, two luxurious hotels in the center of Prague, and the acquisition of a large brewery is being negotiated), Hungary (19\%, mainly taking over the chemical conglomerate Borsodchem by Wanhua) and Poland (9\%) (Yue, 2018, p.12,13).

- Only Hungary in the region has a clear strategy from 2011 towards China and its partners in the East, called keleti nyitás (opening up to the East), which, however, did not bring the expected results so far, although it politically brought the two countries closer together. Available studies also show that Hungary is at the top of the list of 16 countries where the most events and joint ventures with China are organized.

- The current course of cooperation in the framework of $16+1$ proves that it runs almost exclusively on the basis of bilateral agreements of 16 countries with China and did not bring any new quality in regional cooperation (the project of a faster rail linking Budapest with Belgrade, the "five ports" project only on paper, etc.). Moreover, in many countries of the 16, controversies 
are triggered by Chinese financing conditions for the proposed investments, including a significant share of their representatives and companies on construction sites. The same is happening on the EU side, which even came out recently with a screening proposal, that is a close monitoring of China's contracts and investments in its area.

\subsection{Perception of BRI in Poland}

Although born and announced in Poland, neither the concept of $16+1$ nor following it no longer regional but global in its dimension BRI became the focus of Polish foreign policy (Stanzel, Kratz, Szczudlik and Pavlićević, 2016). This is a clear shortcoming, as in the opinion of the author of this study, for the first time in long Chinese history (not counting a brief episode in autumn 1956, when the authorities in Beijing were on the side of the then national leader, seemingly opposing Moscow, Władysław Gomułka) that it is in the interest of China to develop cooperation with Poland. The main reason standing behind this calculation have nothing to do with the feelings, but hard interests: Poland is located on the main land axis of the Silk Road, leading from central China through Xinjiang, Kazakhstan, Russia and Belarus, to Western Europe (Amsterdam, Rotterdam and Hamburg).

Poland has an inalienable asset in relations with the China now gaining global momentum in the form of its location on the map. What has been the Polish real curse for centuries, the location between Russia and Germany, from China's calculated view is the best possible geostrategic asset. It would be worth to use it properly, but - so far - both sides have managed to achieve successes only in the political sphere, and much less in the economic sense, although by assumption it should be the other way around.

The problem of democratic Poland in its relations with China consisted in the fact that for a long time it was overshadowed by a single date: June 4, 1989, when the serious crisis on Tiananmen Square and around took place and was violently resolved in China, while in Poland on the same day instead of a crackdown the first, limited, partly democratic elections were held. Already in September that year it brought about the first democratic government in the countries of the former Eastern bloc, that is the cabinet of Prime Minister Tadeusz Mazowiecki. Later this symbolic and significant date became a kind of „cornerstone” of bilateral relations, strongly - ideologically - burdening them, despite the fact that China approaches cooperation with other countries pragmatically, not ideologically (Góralczyk, 2009, p. 428). Over the next two decades, at least until the great crisis on global (read: the Western) markets, 
the approach of democratic Poland to authoritarian China was saturated with a kind of messianism or a sense of superiority (a new democracy over autocratic - outdated and outgrown - „real socialism”).

The situation changed only at the turn of the first and second decade of the 21st century, partly due to the 2008 crisis, and perhaps even to a greater extent due to the slow awareness of the rapidly growing role of the PRC as an economic and trading giant throughout the West. The political breakthrough in bilateral relations was the visit of President Bronisław Komorowski in China at the end of 2011, when agreements were signed, and mutual relations were brought to the strategic partnership level. Afterwards, during the visit of President Xi Jinping in Poland in June 2016, bilateral relations were raised to the highest possible level: a comprehensive strategic partnership (Xinhua, 2016). The political dialogue at the highest level was supported by: the visit of President Andrzej Duda at the $16+1$ summit in Suzhou (although organized at the level of prime ministers, the Polish side, using the time of changing its own administration, sent the president there, to which the Chinese responded - with an ad hoc organization of the official visit of the Polish president, proving the importance attached to mutual relations) and participation of Polish Prime Minister Beata Szydło at the first BRI summit in Beijing in May 2017.

Unfortunately, the agreements accompanying these visits (moreover, this was not always the case), including nearly 40 signed during the visit of the Chinese head of state in the Republic of Poland, either were not implemented or were significantly slowed down. The decision of the head of the Polish Ministry of National Defense has become a symbol, to not give the Chinese party permission to purchase a plot of land belonging to the Military Property Agency, on which the Chinese side intended to build a - crucial in their plans - communication center on the land Silk Road.

The solution, which was applied as a result of this Polish decision, i.e. signing agreements at the local government level and transferring Chinese rail transport from Łódź to nearby Kutno, proves, firstly, the effectiveness and determination of the Chinese side and, secondly, its great pragmatism. Poland is in Chinese plans an important link in the framework of $16+1$ as well as the BRI and it is to remain as such. As a result, we are dealing with many Chinese enterprises in the Republic of Poland, acting most often of a local level, as a result of agreements with the self-government authorities.

First, the issue of rail connections needs to be addressed. For in this respect Poland is playing not just a central but even a pioneer role in the region. It is due to the fact that even before the announcement of the $16+1$ and BRI initiatives, the Hatrans company located in Lódź came up with the proposal 
to use railway connections for the development of trade relations with China. The first trains from Chengdu in Sichuan province arrived after a two-week trip to Łódź on January 2, 2013. Connections in both directions were initiated in May of the same year, complementing other high-profile and significant connections with China on the Chongqing - Duisburg line, opened in 2011. Regular communication of freight trains on this route began in 2015. At the initial stage, the goods went almost exclusively in one direction - from China to Poland (Czerep, 2017). ${ }^{13}$ It was only after 2015 that the situation began to change a little, and also freight trains going to China, both from Łódź and Kutno, began to be loaded, mainly with agricultural goods, such as fruit, mainly apples or processed vegetables, and over time also chemical and industrial goods. It is estimated that at the end of 2017, approx. 25 percent of all goods arriving by rail to the EU came to Łódź and Kutno, while the dynamics of rail traffic between China and the EU has increased hundredfold over the past decade.

Even before the inauguration of railway connections, which is also difficult to consider as a real coincidence, already in 2009, the Chinese company Covec won a tender for the construction of a motorway section connecting Łódź and Warsaw, which was the first experiment of this type performed by a Chinese company in the EU. This venture, however, did not end in success. Covec was first forced to withdraw from the Polish market and then to pay compensation. It turned out that different business mentalities collided with each other: the Chinese trusted high-level political agreements and assurances, thus acknowledging that they had guanxi, that is the connections with appropriate persons and high-level decision makers, did not make proper market analysis (they entered without a feasibility study), and then collided with the EU legal requirements and slow inflow of money, which triggered the rebellion of Polish Covec subcontractors. In other words, the Chinese mentality based on personal relations and ties has clashed with the EU bureaucratic and institutional order: for them the people and positions count, for us (read: in the EU) institutions, rules, and legal regulations.

Covec's failure, however, did not discourage China. On the contrary, it has even increased its presence in Poland and the region, treating the case of this company as an accident at work and, at the same time, valuable experience on a difficult and demanding EU market.

13 Broader and more in depth on the subject: Jakóbowski, Popławski and Kaczmarski, 2018, p. 1 and 12 . 


\section{Benefits and Risks Associated with BRI}

\subsection{Potential Benefits}

The second area, next to rail and prospects for using high-speed Chinese railways for connections in the region (Budapest - Belgrade), are the first contracts for Chinese investments in the energy sector in the CEE region. The largest and most advanced among them is Cernavoda II power plant in Romania, whose contract is worth 7 billion euros and is to be finalized as early as 2019. Other signed agreements concern nuclear power plants Temelin - Dukovany in the Czech Republic (around 15 billion euros but they are to be launched in the third decade of this century) and Belene in Bulgaria. In this context, what also draws attention are the first Chinese projects and investments in Poland, carried out at the local level, such as the construction of electric traction in the vicinity of Słupsk, Szczecin, Chełm, and Lublin by the Chinese conglomerates China State Grid (the first two) and Sinohydro (the other two).

Two previous investments, or rather acquisitions - of the StalowaWola steelworks by the Liugong company and the Bearing Factory in Krasnik by TriGong, were joined in recent years by such investments as takeover by China Everbright Intl. of Novago company in Mlawa specializing in waste disposal, or Hongbo near Opole (led lighting), Nuctech in Kobyłka (equipment at airports), as well as the construction of the TCL TV assembly plant near Żyrardów, bicycle storage facility in Koszalin (Athletic Group) or candle production near Tarnow (Dalian Talent) (Sarek, 2017, p. 70-73).

As it can be seen, and what can be proved, China's economic and investment presence in Poland is constantly growing, but it is rather selective and single-site. Neither is it common or forced from above. Most agreements, despite excellent political relations at the highest level, are signed at the local or local government level. As such, it is difficult to regard them as carrying a Chinese development model to Poland or even its solutions in industrial policy or management. They should still be considered as limited undertakings. There is a lack of a serious investment (in both directions) in our bilateral relations that could be considered symbolic. On the other hand, the discussion on the involvement of Chinese capital in the construction of the Central Airport (Communication Hub) located between Warsaw and Łódź, should be considered more as media speculation than real agreements, as for now.

However, the most important, inalienable asset in Poland's bilateral relations with China is the fact that the Chinese side has come out with two bold projects, 
first cooperation with the countries of our region in the formula $16+1$ and then as part of the BRI vision. Although it is not known what the fate of these projects will be, and whether - from China's will - there will be a merger between them, it seems that China's interest in Europe and the EU, including Poland, will remain permanent and may even increase due to recent American isolationist visions and looming trade war.

This last factor, due to the specificity of Polish relations and the alliance with the US, will probably not facilitate relations with the new player in our region, which China became, but certainly imposes more creative and strategic thinking on the part of Warsaw as well.

The Chinese side is constantly emphasizing that the BRI has the most open character, practically anyone who wants to, can join the project. On the other hand, Poland not only can but should do it, - for three basic reasons: 1 . Location; 2. Chinese interests related to our country stemming from point $1 ; 3$. The largest potential in the CEE region. However, the degree of this commitment should be constantly measured and dosed carefully, because we are dealing with the asymmetry of potentials and power. China is a new global player with its interests, and Poland is - and should be - located in the West, both in terms of security (NATO) and in the economic sphere (EU, Germany), although in the latter the BRI is proving how important a player China became in practically all areas of the world, including the region $(16+1)$. It is time to draw proper conclusions from that also in Warsaw.

\subsection{Potential Risks}

The basic problem of Poland and other CEE countries in relations with China is that they are asymmetrical relationships. We are dealing with a partner growing into a new superpower, the second economy in the world (the first in the sense of Purchasing Power Parity) and the state that after 2012 is openly proclaiming that it is going to be number one in the world, not only in the economic or commercial dimension. Thus, relations with this partner are of a geostrategic character and require deep strategic reflection.

Poland is and will remain a member of Western alliance (NATO) and, like the countries of the region, it is economically dependent on the EU markets, Germany above all. Thus, closer relations with China may arouse some suspicions of our allies, starting with the US, as well as our trading partners, starting with Germany. These factors must be considered in all agreements and contacts with the Middle Kingdom. This is what the requirements of strategy and geostrategy dictate. 
Chinese initiatives $16+1$, and then the BRI, caused that, whether Poland wanted to or not, both our country and our region entered the great game. It is already visible and obvious that the Chinese have not only appeared on our markets, but also have their interests and fields of influence here. Meanwhile, for example, infrastructure projects strongly enforced by China in many cases are in contradiction with the TEST (Tran-European Transport Network) being pushed by the EU, is just another issue which proves the controversy regarding possible agreements with the Chinese side. In the case of Poland, this requires reflection and consideration of whether we are in favor of the EU Baltic and Adriatic corridor project and whether we want to seek synergy between the project promoted by the Polish authorities, especially the president, to build the Three Seas strategy and similar Chinese proposals aimed at connecting the maritime and the land Silk Road. These initiatives can be treated as separate, or we can try to combine them: the choice belongs to the authorities in Warsaw.

In turn, in the purely economic dimension, the biggest problem is the chronic trade deficit of our region's countries against China, and the $16+1$ and BRI initiatives have changed little in this respect. According to Chinese data, in 2010-2016, Chinese exports to the CEE region increased by 22.74 percentage, from 53.09 to 65.17 billion dollars, while import increased by $41 \%$ at that time, but it closes with much smaller sums - from 6.89 to 9.72 billion dollars. In addition, these turnovers in recent years account for only approx. 10 percent of entire EU trade turnout with China, while the negative trade balance increased from 46.2 to 55.45 billion dollars during this time (Jing and Xiaojing, 2018, p. 2,3$)$. The matter is so serious that it was placed in the final document after the last 16+1 summit in Sofia (Szczudlik-Tatar, 2018).

This deficit is also a major problem in Poland's relations with China. In the period 2009-2017 it almost doubled, from 9 to $14.5 \mathrm{ml}$ dollars, and thus overshadowed the unquestionable success of Poland, which was the highest ever export of Polish goods to China in 2017 in the amount of USD 3.35 billion, increasing more than three times in relation to the level before the launch of the $16+1$ formula. According to data provided by the Central Customs Office of the PRC, which do not fully coincide with the Polish Central Statistical Office, the bilateral trade increased in 2012-2017 from 12.3 to - for the first time in history - over 20 billion dollars according to Chinese data (17.85 according to the Polish Central Statistical Office). ${ }^{14}$

14 https://www.bankier.pl/wiadomosc/Eksport-z-Polski-do-Chin-najwyzszy-w-historii-7568470.html (16.07.2018). 
The ambiguity in the statistics on trade with China is that a significant part of it goes through Hong Kong and tax havens like the Cayman Islands or the Virgin Islands. Thus, it is more difficult to obtain homogeneous and more precise data. Whereas the basic problem of the serious trade deficit naturally puts a great shadow on our entire bilateral relationship. According to the calculations of one Chinese author, the cumulated Polish deficit in trade with the PRC in the period 2008-16 amounted to USD 154.4 billion (Yue, 2018, p. 9).

This state of affairs is worrying because it must worry. All the more so because in the Chinese commodity offer there are more and more highly processed goods including high technologies, while raw materials or unprocessed goods prevail in ours, only recently supplemented with chemicals or pharmaceutical products. This way, the country which the EU (together with the US) is denying the Market Economy Status (MES) and is designed as a "developing country" exports higher quality goods to an area formally belonging to the EU, thus meaning one of the most developed organisms in the world.

This is not the only paradox proving that the approach to China should be reevaluated as soon as possible. Meanwhile, only Hungary has developed a strategy for cooperation with China and a political will to continue it. Meanwhile only Slovakia - a country with a somewhat poorly developed scale of cooperation with China - has developed a special Action Plan for the period 2017-2020, complemented by the government's concept for development of economic relations with PRC (Kironská and Turcsányi, 2017, p. 9). Whereas such documents would certainly be useful in all CEE countries.

In Poland, regular analyses of China at the central level are carried out, at a comprehensive, but so far insufficient level, by only two institutions: the Polish Institute of International Affairs (PISM) and the Center for Eastern Studies (OSW). The first is focused on the studies of the entire foreign policy of the state, in which the approach to China or emerging markets plays only a marginal role (only two analysts dealing exclusively with China), and the other is much more concentrated on post-Soviet areas than the East Asia region. Meanwhile, the latter - along with China and Taiwan, also both Koreas and Japan - is playing an increasingly important role on the international arena, not only in the economic and commercial dimension, but also strategically. It would be worth drawing proper conclusions from this by setting up a special team or even an analytical institute dealing exclusively with this area. Due to the new and constantly growing role of East Asia it should be created as soon as possible as a fulfillment of the well-understood interests of the state. 


\section{Conclusions}

The so-called fifth generation of PRC leaders led by Xi Jinping, in power since the end of 2012, broke with the previous policy of modesty, low profile and (re) building its own power quietly, without drawing attention of the outside world, as postulated in the political testament of a visionary of first market-oriented reforms (1978), and then of China's inclusion in globalization (1992), Deng Xiaoping. The new team came out with very bold projects both on the domestic ("two centennial goals") and international stage, in the form of OBOR - BRI. From now on, relations with China should be treated as with a newly emerging superpower, having an impact on the balance of power in the world, through its weight and rank restoring the new multipolar world order, with China having more and more to say in many areas, also in the sphere of development models, what this volume is all about, and to what - as this analysis demonstrates - the Polish side apparently does not give proper attention.

The previous $16+1$ vision of 2012 , preceding the BRI, is a good platform for cooperation between China and the region, although from the beginning it raised suspicions or controversy over China's „divide and rule” principles, be it in the US or EU institutions and major capitals of EU states, starting with Berlin, as - as shown by available statistics and data - the entire CEE region is economically and commercially dependent on Germany. This factor must be constantly included in Polish calculations, when considering any development of relations with China, a desirable partner, as it has its own interests here, and in addition rich capital resources and own projects and proposals.

It is the external factor that brought about a new dynamics, or rather turbulence, into relations both with China and the EU by the new American administration of Donald Trump, in power from January 2017. Not only some countries of the 16 (like Estonia, Lithuania or Albania) began to hesitate about their further participation in this format, but they also began to think about their further functioning in this formula. At the same time the originators themselves, that is the Chinese side, as evidenced by - never officially confirmed, but also not negated through Beijing - concepts of the organization of the $16+1$ summits not once a year but once every two years (the next is announced in Croatia, but without a date), and including „oversensitive” Germany into this formula. More and more signals from China also indicate that the $16+1$ formula will become an integral part of the BRI. 
This is primarily in response to the American concepts of unilateralism, protectionism, and even commercial war implemented by the Donald Trump administration, that the Chinese side is increasingly pushing its own concepts, that is the support for globalization and the principles of free trade and rules in force at the WTO. Moreover, the Chinese leaders oppose the project America First, by promoting their concept of community of shared destiny, and therefore a community of interests based on globalization, where in addition - according to Beijing - the principle of mutual benefits (win-win) is supposed to dominate, which, however, not all Chinese partners take at face value.

This approach of China and its growing potential, including investment potential (from 2014, outgoing Chinese investments are larger than those that come to it) is the reason for which literally every country in the world should carry out some examination of conscience in relations with this new colossus. This is also true of Poland, the most important country in the CEE region, in addition located on the main land route of the Silk Road drawn by China. Besides the initiated by the Polish side railway transports between the two countries, these are two inalienable advantages of our country in relations with China, which in addition, is guided by its own interests, and not only wants to come to Poland, but is actually coming - as an investor and a new player.

Unfortunately, as the present analysis proves, a very good network of relations at the highest political level, including visits of presidents of both countries to each other, have not been transformed into real economic success so far, and Poland is still struggling with a chronic deficit in trade with this partner, while new agreements and contracts are signed more at the local than at the national level. The current authorities in Poland, after the first visible admiration in relations with the new strongman, later apparently slowed cooperation with China, which should be understood foremost as a response to a completely new dynamics of relations in the US-EU-China triangle. Similarly, not without meaning to the course of bilateral Poland - China relations, unsurprisingly, are very close ties and cooperation between China and Russia, treated in Warsaw biggest antagonist of Poland.

However, this does not change the fact that the large-scale concept of BRI is and will be pushed through by Beijing, and Poland is considered in these calculations as an important partner. It would be worth to use our considerable advantages properly. What is needed, however, is the political will, as well as the wider expert base of decision-makers, able to develop - indispensable in the present circumstances - a strategy of relations with China. We have such potential in the personal sense. All that is needed is imagination and political will to use it. 


\section{References}

Allison, G. (2017). Destined for War. Can America and China Escape Thucidydes Trap? New York: Houghton Mifflin Harcourt.

b.d. (2017). "Chiński Dylemat" (Chinese Dilemma), Polski Przeglad Dyplomatyczny 3(70), July-September.

Bartosiak, J. (2016). Pacyfik i Eurazja. O wojnie (Pacific and Eurasia. On War). Warszawa: Wydawnictwo CSPA.

Czerep, J. (2017). Influence of the Łódź-Chengdu railway on the perception of $16+1$ in Poland. China - CEE Institute Working Paper, No. 5, Budapest, 15 November.

Deng, J. and Liu, X. (2018). Deepening the " $16+1$ cooperation" relationship to foster the new growth pole of Sino-EU Trade. China - CEE Institute Working Paper, No. 13, 22 June.

EEAS. (2016). EU - China 2020. Strategic Agenda for Cooperation. Acquired from: https:// eeas.europa.eu /sites/eeas/files/20131123.pdf.

Godemont, F. and Vasselier, A. (2017). China At the Gate. Anew Power Audit of EU - China Relations. ECFR, December. Acquired from: https://www.ecfr.eu/page/-/China_Power_ Audit.pdf.

Góralczyk, B. (2017 a). China's interest in Central and Eastern Europe: enter the dragon. European View, 16, June.

Góralczyk, B. (2017 b). Eastern-Asian development model: the growth-fostering state, In: J. Yifu Lin, A.Z. Nowak (eds.), New Structural Economics for Less Advanced Countries, Warsaw: Wydawnictwo Wydziału Zarządzania UW.

Góralczyk, B. (2018). Wielki Renesans. Chińska transformacja i jej konsekwencje (Great Renaissance. Chinese Transformatrion and its Consequences). Warszawa: Wydawnictwo Naukowe Dialog.

Góralczyk, B. (Ed.). (2009) Poland - China. Yesterday, Today, Tomorrow, Toruń: Wydawnictwo A. Marszałek.

https://cen.acs.org/business/petrochemicals/BASF-considering-10-billion-investment/96/ web/2018/07 (16.07.2018).

https://global.handelsblatt.com/politics/eu-ambassadors-beijing-china-silk-road-912258 (20.07.2018).

https://www.bankier.pl/wiadomosc/Eksport-z-Polski-do-Chin-najwyzszy-w-historii-7568470. html (16.07.2018).

https://www.project-syndicate.org/bigpicture/trump-s-trade-war-expands (16.07.2018).

https://www.project-syndicate.org/bigpicture/trump-s-trade-war-expands (16.07.2018).

Huang Ping, Liu Zuokui (eds.), China - CEEC cooperation and the 'Belt and Road Initiative', Beijing: China Social Sciences Press.

Jakóbowski, J., Popławski, K. and Kaczmarski M. (2018). Kolejowy Jedwabny Szlak. Połączenia kolejowe UE - Chiny: uwarunkowania, aktorzy, interesy (Railway Silk Road: Railway connections the EU - China: conditions, actors, interests), Prace OSW, 72, Warszawa, February.

Jing, D. and Xiaojing, L. (2018). Deepening the "16+1 cooperation" relationship to foster the new growth pole of Sino-EU Trade. China - CEE Institute Working Paper, No. 13, 22 June.

Joić, S. (2017). How Serbia perceives „The Belt and the Road” Initiative and 16+1 Cooperation. China - CEE Institute Working Paper, No. 9. Budapest, 15 November. 
Kironská, K. and Turcsányi, R.Q. (2017). Slovak Policy towards China in the age of Belt and Road Initiative and 16+1 Format. China - CEE Institute Working Paper, No. 2. Budapest, 15 November.

Lin, Y. (2018). Economic 'highway' with three speed tracks and destinations between China and CEE.China - CEE Institute Working Paper, No. 14, Budapest, 22 June.

Maddison, A. (2007). Chinese Economic Performance in the Long Run (2nd edition).OECD, Paris: Development Centre Studies.

MERICS and Rhodium Group. (2017). Chinese Investment in Europe: record flows and growing imbalances. Joint report by MERICS and Rhodium Group. Berlin: MERICS - Mercator Institute for China Studies, January. Acquired from: https://www.merics.org/en/paperson-china/chinese-investment-europe-record-flows-and-growing-imbalances (15.07.2018).

Oehler-Sincai, I.M. (2018). 16+1, a New Issue in China-EU Relations? China - CEE Institute Working Paper, No 1. Budapest, 22 June.

Pillsbury, M. (2016). The Hundred-year Marathon. China's strategy to replace America as the global superpower. New York: St. Martin's Griffin.

Sarek, Ł. (2017). Chiński dylemat polskiej polityki zagranicznej (Chinese Dilemma of Polish Foreiogn Policy), Polski Przegląd Dyplomatyczny „Chiński Dylemat”, 3 (70), July-September.

Stanzel, A., Kratz, A., Szczudlik, J. and Pavlićević, D. (2016).China's investment in influence: the future of 16+1 cooperation. ECFR, December.

Szczudlik-Tatar, J. (2018). Perspektywy format Europa Środkowa - Chiny po szczycie w Sofii (Perspectives of CEE - China Cooperation after the Sofia Summit), Biuletyn PISM, 91, 13 July.

Winter, T. (2016). One Belt, One Road, One Heritage: Cultural Diplomacy and the Silk Road. The Diplomat, 29 March.

Xi, J. (2014). The Governance of China. Mainland China: Foreign Languages Press.

Xi, J., President Xi Addresses the 2018 Boao Forum for Asia in Hainan, Boa., 11 April. Acquired from: https://www.uscnpm.org/blog/2018/04/11/transcript-president-xi-addresses2018-boao-forum-asia-hainan/ (15.07.2018).

Xin, Ch. (ed.). (2017). How Hungary Perceives Belt \& Road Initiative and China-CEEC Cooperation. Beijing: China Social Sciences Press.

Xinhua. (2016). China, Poland lift ties to comprehensive strategic partnership. Acquired from: http://www.xinhuanet.com/english/2016-06/21/c_135452132.htm (16.07.2018).

Xinhua. (2017). Xi Jinping's keynote speech at the World Economic Forum. Davos, 27 January. Acquired from: http://www.china.org.cn/node_7247529/ content_40569136.htm.

Yue, L. (2018). Economic 'highway' with three speed tracks and destinations between China and CEE.China - CEE Institute Working Paper, No. 14, Budapest, 22 June.

Zhang, X. (2016). Chinese Capitalism and the New Silk Roads. Aspen Quarterly, 4.

Zou, L. (2018). An Analysis of Germany's Suspicions about „16+1 Cooperation” and China's Possible Countermeasures - From the Perspective of European Integration. China - CEE Institute Working Paper, No. 5. Budapest 22 June.

Zuokui, L. (2017). Europe and the "Belt and Road" Initiative: Responses and risks. Beijing: Paths International Ltd./China Social Sciences Press/CASS. 